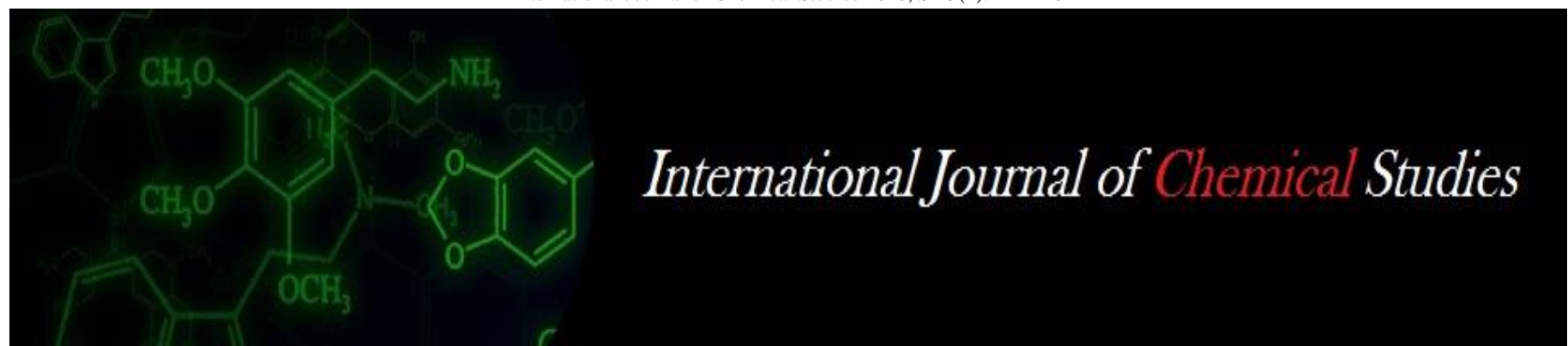

P-ISSN: 2349-8528

E-ISSN: 2321-4902

www.chemijournal.com

IJCS 2021; SP-9(1): 142-146

(C) 2021 IJCS

Received: 10-12-2020

Accepted: 05-01-2021

SKS Rajpoot

Crop Research Station,

ANDUAT, Ghaghraghat,

Bahraich, Uttar Pradesh, India
Corresponding Author:

SKS Rajpoot

Crop Research Station,

ANDUAT, Ghaghraghat,

Bahraich, Uttar Pradesh, India

\section{Frontline demonstrations: Integrated crop management (ICM) in field pea (Pisum sativum L.) with an innovative approach of line sowing technology for higher yield at Sonbhadra district of Uttar Pradesh}

\section{SKS Rajpoot}

DOI: $\underline{\text { https://doi.org/10.22271/chemi.2021.v9.i1c.11515 }}$

\begin{abstract}
Field pea (Pisum sativum L.) is a good source of dietary protein to complement the cereal based diet, particularly for vegetarian masses in the country. It is a Rabi pulse crop which is highly productive and is grown for food, feed and vegetable. The changing climate has its influence on flower drop, poor pod setting and low yields due to insect pest and disease incidence In this regard of view ICAR- Krishi Vigyan Kendra, Sonbhdra Uttar Pradesh conducted 180 frontline demonstrations (FLDs) in an area of 30 ha area in various farmers field of different villages of Sonbhdra district during the period from 2014-15 to 2017-18. The demonstration was conducted to enhance the yield of field pea through integrated crop management technology (ICM) along with line sowing of field pea with variety Jay KPMR 522. The new technique red gram transplanting with ICM yielded highest average highest yield of $23.27 \mathrm{q} / \mathrm{ha}$ where as in farmer's practices the average yield was to $11.16 \mathrm{q} /$ ha which was 109.18 percent increase in the yield over farmer practices. The average technological gap, extension gap and technological index noticed were $1.73 \mathrm{q} / \mathrm{ha}, 12.11 \mathrm{q} / \mathrm{ha}$ and 6.92 percent respectively and recorded the average net profit of Rs. $80,863 /$ - per ha under demonstration while it was Rs 38,769/- per ha under farmer practices. Benefit cost ratio was 5.01 under demonstration where as it was 2.91 under farmer practices.
\end{abstract}

Keywords: Yield gap, technology gap, integrated crop management, technology index and B:C ratio

\section{Introduction}

Field Pea (Pisum sativum L.) is a popular pulse crop in India. India is the largest producer, consumer and importer of pulses. Garden pea and field pea are cultivated in India. Garden pea is harvested as green pods and cooked as fresh or canned for subsequence uses. Field pea is generally grown for dry seeds which are used for a variety of culnary and pulse. According to Reddy $2010^{[11]}$, dry pea is highly nutritive containing high proportion of digestive protein $(22.5 \%)$ carbohydrates $(62.1 \%)$ fat $(1.8 \%)$ minerals (calcium, Iron) and Vitamins (Riboflavin, Thiamine). The most probable centre of origin of pea is Mediterranean region of Europe and Central Asia. India is one of the major pulse producing countries contributing about 33 per cent of world area and 25 per cent of world production of pulses. Pulses are also an important component of Indian agricultural economy next to food grains and oilseeds in terms of acreage, production and economic value (Choudhary, 2009) ${ }^{[3,4]}$. The important pulse crops in India are chick pea, pigeon pea, mung bean, urd bean, lentil and field pea (Ali and Gupta 2012) ${ }^{[1]}$. However India's rank in productivity is low, 24th in chick pea, 9th in pigeon pea, 23rd in lentil and 98th in total pulses (Reddy, 2004) ${ }^{[11]}$. In India, production of pulses is around 19.3 million tonnes (ESI, 2015) ${ }^{[1]}$ with a very low average productivity of $764 \mathrm{~kg} / \mathrm{ha}$. Currently, total area under pulses is 26.3 million ha (Choudhary and Suri, 2014) ${ }^{[3,4]}$. However, in the case of Lentil, the average yield in India $(629 \mathrm{~kg} / \mathrm{ha})$ is 25 per cent lower than the world average $(1053 \mathrm{~kg} / \mathrm{ha})(\mathrm{FAO}, 2007)^{[6]}$. There is a stark decline in the availability of pulses in the country from $69 \mathrm{~g} / \mathrm{capita} /$ day in 1961 to $33 \mathrm{~g} / \mathrm{capita} /$ day in 2009-10 (ICMR recommends $65 \mathrm{~g} /$ day/capita) (Ali and Gupta 2012) ${ }^{[1]}$. To overcome the problem of protein energy malnutrition, a minimum of $50 \mathrm{~g}$ pulses/capita/day should be available in addition to other sources of protein. 
Thus, to make the nation pulse sufficient, average yield level has to increase substantially up to $1200 \mathrm{~kg} / \mathrm{ha}$ by 2020 (The Hindu 2005) ${ }^{[13]}$. Due to the mismatch between supply and demand of pulses, prices of pulse crops have increased exorbitantly. Even though pulses are very important for India in terms of share of production and consumption, in term of importance, both farmers and government have ignored them. In India, the irrigated area under pulses was only 12 per cent, while under wheat and paddy, it was more than 60 per cent of the total area. (Materne and Reddy, 2007; Reddy, 2009) ${ }^{[11]}$. Pulse productivity in India is much lower than other pulse producing countries. This is mainly because of unavailability of quality seed at desired time, cultivation on marginal and sub-marginal lands, injudicious use of fertilizers and nonadoption of crop management practices and poor marketing infrastructure (Chandra, 1994; Choudhary, 2013) ${ }^{[3,4]}$.

India is the second largest producer of pea in the world after Russia. Field pea is cultivated on 6.51 million ha area with the total production of 10.95 million tons. Field pea is distributed in Asia, Africa, Europe, North America, Australia, China, Russian, Ukraine, India Ethiopia, France Canada and USA. In India the average productivity of field pea is $906 \mathrm{~kg} / \mathrm{ha}$. The major field pea growing states are Uttar Pradesh Madhya Pradesh, Bihar and Maharashtra. In Madhya Pradesh it is cultivated in 3.48 lakh ha area with 2.80 lakh tonnes production. Field pea in Panna district occupies 11680 ha with an average productivity of $1666 \mathrm{~kg} / \mathrm{ha}$ of Field pea Crop. Bindhya region. It is having very typical land topography, soil type and physio-chemical properties. So, the National Agricultural Research System including ICAR Institutes, Agricultural Universities, All India Coordinated Research Projects and Krishi Vigyan Kendras to develop and demonstrate new technologies of various pulse crops. A large number of region-specific and widely adapted high yielding short duration varieties of pulses with tolerance to biotic and abiotic stresses have been developed. (Kumar and Srivatava 2015) ${ }^{\text {[9] }}$, established the impact of reproductive duration on yield in lentil. ICAR has also made sincere efforts in producing required quantity of breeder seeds of major pulse crops. Since 2010-11 ICAR had envisioned to undertake well designed programme of Technology Demonstration for Harnessing Pulses Productivity through KVKs.

Frontline demonstration programme was effective in changing attitude, skill and knowledge of improved practices of HYV of urd including adoption this also improved the relationship between farmers and scientist and built confidence between them. (Kirar et al. 2006) ${ }^{[8]}$, reported that the farmers who adopted demonstration acted also as source of information and pure seed for wider dissemination of HYV of urd for the farmers. (Kangali 2012) ${ }^{[7]}$, revealed that in case of level of adoption, as observed in low category, 25.00 per cent farmers decreased in adopter condition over non adopter condition. On the other hand, in partial and full adoption condition 17.50 and 7.50 per cent farmers increased in adopter condition over non adopter condition respectively. (Verma 2013) ${ }^{[14]}$, shows the distribution of beneficiaries according to their change of area after conducting the FLD on their field.

\section{Materials and Methods}

Being a winter season crop it requires a cool growing season with moderate temperature throughout the life. High temperature is more injurious to pea crop than frost. Frost can damage the plants during flowering stage. High humidity associated with cloudy weather results into spread of fungal diseases like damping-off and powdery mildew. Optimum monthly temperature suitable for growth is $13-18{ }^{\circ} \mathrm{C}$. The present study was carried out by the Krishi Vigyan Kendra, Sonbhadra Achrya Narendra Deva University of Agriculture \& Technology, Ayodhya (U.P.) during rabi season of 2014-15 to 2017-18 four consecutive years in the farmer's field in two block Ghorawal and Robertsganj of 10 adopted villages viz., Silhata, Pagia, Bari, Obradeeh, Banjaria, Pithori, Gourahi, Ailahi,Papi, Ghuwani and Manapur of Sonbhadra district. The soil was red, black with shallow depth and rocky nature located in undulated terrain is another problem of the district. Each demonstration was conducted in an area of 0.4 ha and 0.4 ha area. All 180 front line demonstrations in 30 ha area were conducted in different villages. The improved technologies package included field pea wilt resistant varieties, line sowing, integrated nutrient management and timely weed removal. The variety of field pea Jay (KPMR522 ), on date of sowing 25 Oct $-1^{\text {st }}$ November in all years. Most of the participating farmers kept a control plot from comparison. The cropping period was split into different growth period. All the farmers were imparted field training on the particular operation of the field pea cultivation. Such an approach was very encouraging and participation was cent percent. The Technology demonstrated was improved field pea variety -Prakash sown in line with row spacing of $30 \mathrm{~cm}$ at a seed rate $100 \mathrm{~kg} / \mathrm{ha}$, after seed treatment with Carboxin + Thiram @ $2 \mathrm{~g} / \mathrm{kg}$ seed along with bio-fertilizer Rhizobium+PSB each @ 10g/kg seed. basal Fertilizers applied as a basal dose at the rate of $20 \mathrm{~N}: 50 \mathrm{P}: 20 \mathrm{~K} \mathrm{~kg} / \mathrm{ha}$ through Urea, Single super phosphate and MOP respectively, seeds+pheromone trap @ 04/plot + bird percher (Tshaped pegs) @ 10/plot + spray of 250 LE, HaNPV after 10-days of second spray, spraying of Neem Seed Kernel Extract (NSKE) @ 5\% at 15-days interval from pod formation stage. Application of fungicide for management of Powdery Mildew disease on spraying with Dinocap @ $1 \mathrm{ml} /$ litre of water and repeat after 10-15 days. Spray the crop with Mancozeb 75 WP @ 2 g / liter of water to control rust disease. Insect/pest control to different pest viz: Pea Stem fly, Leaf Miner, Pea Aphids and Spiny Pod Borer to spray of 1.25 liter of cypermethrin in 1000 liter of water per hectare or Spray 1.25 liter of Dimethoate 30 EC or oxydemeton methy (Metasystox) $25 \mathrm{EC}$ in 1000 liter of water per hectare. The weed control from field pea crop should be free from weeds for the period up to 40-50 days after sowing for that two hand weeding at three and six weeks after germination. For chemical weed control application of Pendimethalin (STOMP) 30 EC @ $0.75-1 \mathrm{~kg}$ a.i./ha as pre-emergence and for post emergence apply Metribuzin 70\% WP @ $0.25 \mathrm{~kg}$ a.i./ha at $15-20$ day after sowing in 400-600 liter of water. One or two irrigations at 45 DAS and if needed, at pod filling stage. The crop was harvested during 20 March to 30 March. The primary data was collected from the selected FLD Farmers by random crop cutting method while personal interview schedule for technology performance and acceptance. Before harvesting final plant height $(\mathrm{cm})$ was recorded. The crop was harvested at maturity stage. From front line demonstration plots and farmers practice plot (control plot) and finally extension gap, technology gap, and technology index were calculated as given as formula suggested by Samui et al. (2000) ${ }^{[12]}$ and Dayanand et al. (2012) ${ }^{[5]}$ as given below:

1. $\%$ increase over farmers practices $=$ Improved practices Farmers practices / farmers practices x 100

2. Technology gap $=$ Potential yield - Demonstration yield

3. Extension gap $=$ Demonstration yield - farmers yield 
4. Technology index $=[($ Potential yield - Demonstration yield) /Potential yield ] x 100

The data of adoption and horizontal spread of technologies were collected from the farmers with the interaction them. Data were subjected to suitable statistical methods. The following formulae were used to assess the impact on different parameters of field pea crop.

1. Impact of yield $=$ Yield of demonstration plot- yield of control plot/Yield of control plot X 100

2. Impact on adoption ( $\%$ change $)=$ No. of adopters after demonstration- No. of adopters before demonstration /No. of adopters before demonstration X 100

3. Impact on horizontal Spread $(\%$ change $)=$ After area (ha) - Before area (ha)

\section{Results and Discussion}

\section{Major constraints in lentil production}

Socio economic survey of the adopted villages for the demonstration showed that majority of the lentil farmers were resource poor having small land holdings. Major constraints in lentil production were identified and documented. On perusal of data presented table -1and figure 1 it was found that major constraints in lentil production were non availability of the quality seed of high yielding varieties $(61.11 \%)$ was given the top most rank followed by low technical knowledge (57.22\%), weed infestation (52.78\%), Use of higher seed rate $(51.67 \%)$, low fertility status (47.78\%), damage of crop by the wild animals $(39.44 \%)$, wilt disease $(37.78 \%)$, and aphid $(28.89 \%)$.

Yield, extension gap, technology gap and technology index The productivity of field pea from mean grain yield of 23.27 $\mathrm{q} / \mathrm{ha}$ under improved practice on farmer's field as compared to farmer's practices mean of grain yield $11.19 \mathrm{q} / \mathrm{ha}$ and grain yield increase $109.18 \%$ over farmer's practices presented in table-2 and figure 2. The similar finding of Mukherjee (2016). The extension gaps from $12.11 \mathrm{q} / \mathrm{ha}$ during the period of demonstration emphasized the need to educate the farmers through various extension tools viz. training programmes, kisan gosthies, distribution of literatures for the wider adoption of improved agricultural production technologies to reverse this trend of wide extension gap. More and more use of latest production technologies with high yielding varieties will subsequently change this alarming trend of galloping extension gap. The technology gap was $1.73 \mathrm{q} / \mathrm{ha}$. Observed may be attributed to the variability in edaphic and climatic factors. The technology index (\%) was $6.92 \%$ Technology index was recorded to be decreased over the successive years of study.

\section{Economic analysis}

Different input variables like seed, fertilizers, herbicides and pesticides were considered in economic analysis of FLD demonstrations as well as for farmers practice. The inputs and outputs price of commodities prevailed during the FLD period, were taken for calculating cost of cultivation, net returns and $\mathrm{B}: \mathrm{C}$ ratio. (Table 3). The investment on production by adopting improved technology with a mean value of Rs. 16153/ha against farmers practice where the variation in cost of production with mean value of Rs. 13331/ha. Cultivation of field pea under improved practices fetch higher net return of mean value Rs. 80,863/- compared to farmer practice to mean amount of Rs. 38,769/- ha. The additional net return with mean value of Rs.42, 094/- ha over farmer practice. The B:C ratio of improved technology was 5.01 and farmers practice was 2.91 .

\section{Satisfaction level of farmers}

The result of Satisfaction level of famers was high $68.3 \%$, medium $76.1 \%$ and low is $51.1 \%$ are presented in table 4 and figure 3 .

\section{FLD on horizontal spread of rice}

The FLD produced a significant positive result and provided an opportunity to demonstrate the productivity potential and profitability of the latest technology (intervention) under real farming situation. Therefore the study concludes that FLDs conducted by KVK, Sonbhadra made significant impact on horizontal spread of this technology $48.57 \%$.

\section{Conclusion}

Frontline demonstrations were carried out in a systematic and scientific manner on farmer's field to show the worth of improved production technology of lentil and convincing farmers for further adoption. Response receives from different farmer's revealed that farmer were satisfied with potentialities of demonstrated technology.

Table 1: Ranks for different constraints $(\mathrm{f}=180)$ given by farmers

\begin{tabular}{|c|c|c|c|c|}
\hline S. No. & Constraints & Farmers & Percentage & Rank \\
\hline 1 & Non availability of the seeds of high yielding varieties & 110 & 61.11 & I \\
\hline 2 & Low technical knowledge & 103 & 57.22 & II \\
\hline 3 & Use of higher seed rate & 93 & 51.67 & IV \\
\hline 4 & Low soil fertility & 86 & 47.78 & V \\
\hline 5 & Weed infestation & 95 & 52.78 & III \\
\hline 6 & Damage by bull & 71 & 39.44 & VI \\
\hline 7 & Wilt disease & 68 & 37.78 & VII \\
\hline 8 & Aphids & 52 & 28.89 & VII \\
\hline
\end{tabular}




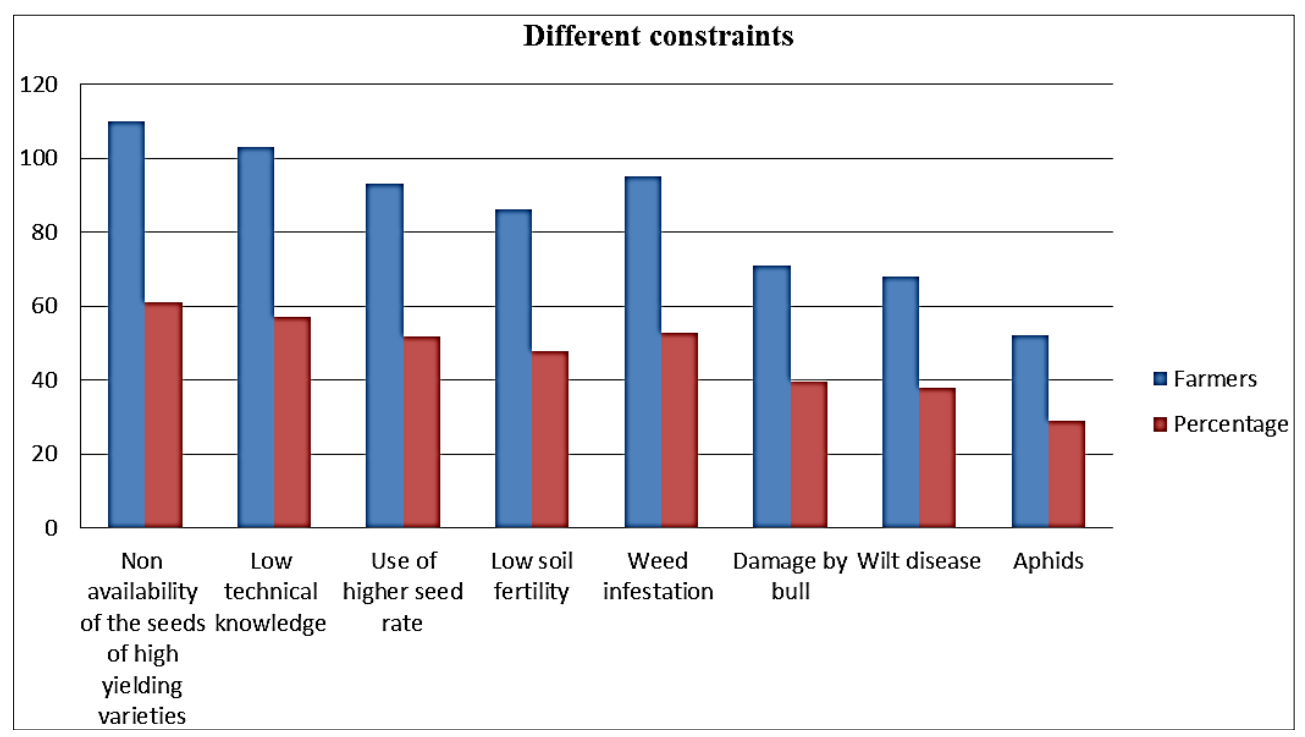

Fig 1: Ranks for different constraints

Table 2: Yield and gap analysis of FLD on field pea at farmer's field

\begin{tabular}{|c|c|c|c|c|c|c|c|c|}
\hline Year & Area (ha) & $\begin{array}{c}\text { Potential grain yield } \\
(\mathbf{q} / \mathbf{h a})\end{array}$ & \multicolumn{2}{|c|}{ Grain yield (q/ha) } & $\begin{array}{c}\text { \% increase over } \\
\text { FP }\end{array}$ & $\begin{array}{c}\text { Extension gap } \\
(\mathbf{q} / \mathbf{h a})\end{array}$ & $\begin{array}{c}\text { Technology gap } \\
(\mathbf{q} / \mathbf{h a})\end{array}$ & $\begin{array}{c}\text { Technology } \\
\text { index }\end{array}$ \\
\hline & & & FLD & FP & & & & \\
\hline $2014-15$ & 10.00 & 25 & 22.23 & 10.10 & 120.10 & 12.13 & 2.77 & 11.08 \\
\hline $2016-17$ & 10.00 & 25 & 23.10 & 11.18 & 106.62 & 11.92 & 1.90 & 7.60 \\
\hline $2017-18$ & 10.00 & 25 & 24.48 & 12.19 & 100.82 & 12.29 & 0.52 & 2.08 \\
\hline Mean & 30.00 & 25 & 23.27 & 11.16 & 109.18 & 12.11 & 1.73 & 6.92 \\
\hline
\end{tabular}

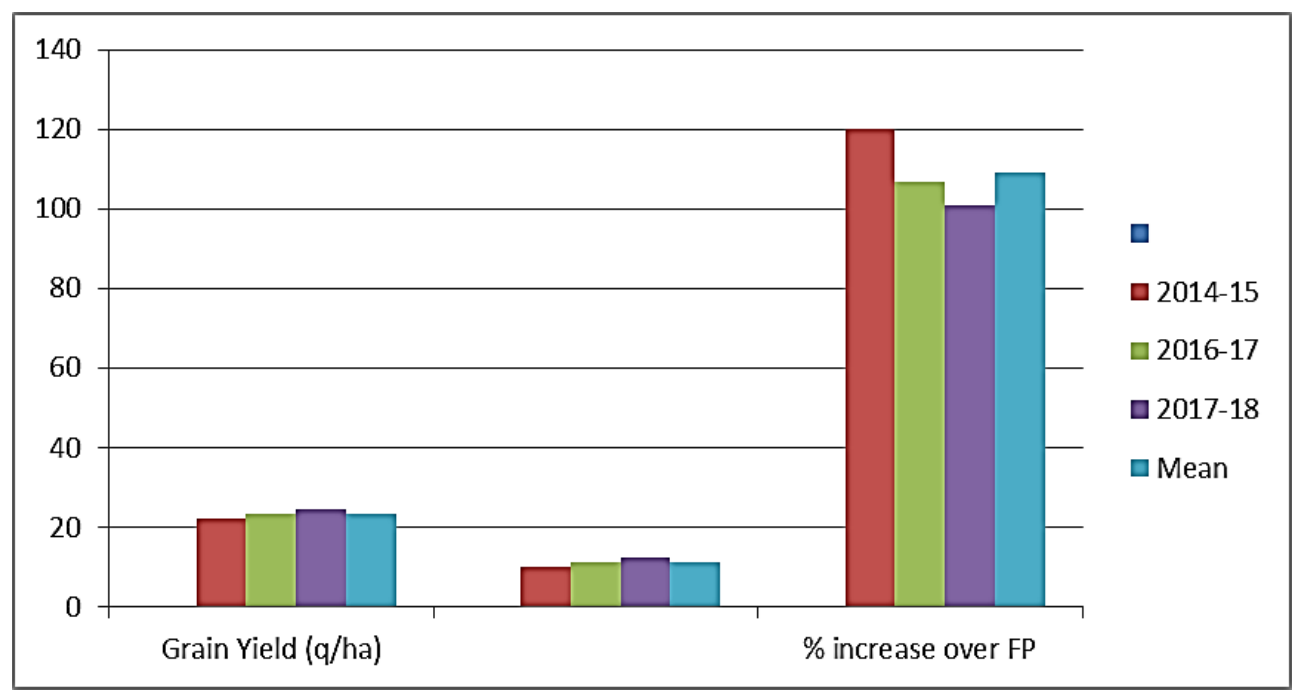

Fig 2: Yield and gap analysis of FLD

Table 3: Economic analysis of front line demonstrations field pea at farmers field

\begin{tabular}{|c|c|c|c|c|c|c|c|c|c|c|c|c|}
\hline \multirow[t]{2}{*}{ Year } & \multirow[t]{2}{*}{$\begin{array}{l}\text { Potential grain } \\
\text { yield }(q / h a)\end{array}$} & \multicolumn{2}{|c|}{ Cost of cash input } & \multirow[t]{2}{*}{$\begin{array}{c}\text { Additional cost in } \\
\text { demonstrations } \\
\text { (Rs./ha) }\end{array}$} & \multirow[t]{2}{*}{\begin{tabular}{|c|}
$\begin{array}{c}\text { Sale price of } \\
\text { grain (MSP) } \\
\text { (Rs./qt) }\end{array}$ \\
\end{tabular}} & \multicolumn{2}{|c|}{$\begin{array}{l}\text { Grain yield } \\
\text { (q/ha) }\end{array}$} & \multicolumn{2}{|c|}{$\begin{array}{l}\text { Total returns } \\
\text { Rs. (ha }\end{array}$} & \multirow[t]{2}{*}{$\begin{array}{l}\text { Extra } \\
\text { returns }\end{array}$} & \multicolumn{2}{|c|}{$\begin{array}{c}\text { Incremental } \\
\text { benefit: Cost } \\
\text { ratio }\end{array}$} \\
\hline & & FLD & FP & & & FLD & FP & FLD & FP & & FLD & FP \\
\hline 2014-15 & 25 & 14800 & 10200 & & 3075 & 22.23 & 10.10 & 68357 & 31058 & 37300 & 4.62 & 3.04 \\
\hline $2016-17$ & 25 & 16200 & 14500 & 1700 & 3400 & 23.10 & 11.18 & 78540 & 38012 & 40528 & 4.85 & 2.62 \\
\hline 2017-18 & 25 & 17459 & 15293 & 2166 & 3950 & 24.48 & 12.19 & 96696 & 48151 & 48546 & 5.54 & 3.15 \\
\hline Mean & 25 & 16153 & 13331 & 2822 & 3475 & 23.27 & 11.16 & 80863 & 38769 & 42094 & 5.01 & 2.91 \\
\hline
\end{tabular}

Table 4: Extent of farmers satisfaction over performance of FLDs $(n=180)$

\begin{tabular}{|c|c|c|}
\hline Satisfaction level & Number & Percent \\
\hline High & 123 & 68.3 \\
\hline Medium & 137 & 76.1 \\
\hline Low & 92 & 51.1 \\
\hline
\end{tabular}




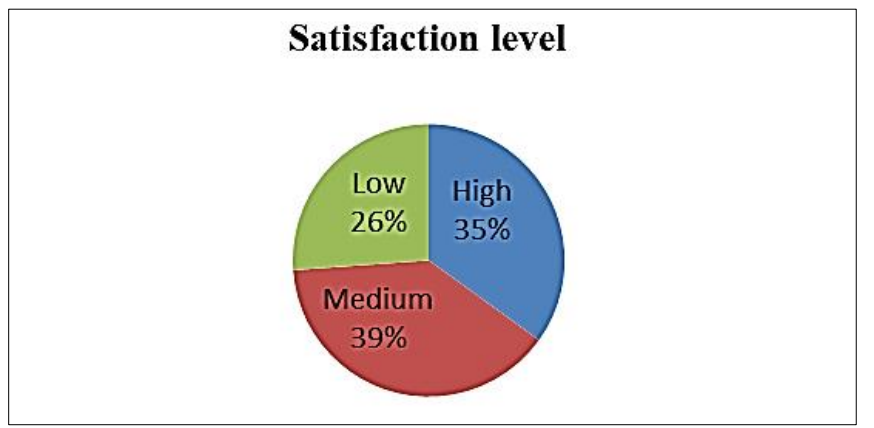

Fig 3: Farmers satisfaction level

\section{References}

1. Ali M, Gupta S. Carrying capacity of Indian agriculture: Pulse crops. Current Science. ESI. (2015). The Economic Survey 2014-15. The Economic Survey of India, New Delhi 2012;102(6):874-881.

2. Chandra S. Increasing pulse production in India, Proceedings of Symposium on Increasing Pulse Production in India-Constraints and opportunities, New Delhi1994, P23-39.

3. Choudhary AK. Role of phosphorus in pulses and its management. Indian Farmers’ Digest 2009;42(9):32-34.

4. Choudhary AK, Suri VK. Scaling up of pulses production under frontline demonstrations technology programme in Himachal Himalayas, India. Communication in Soil Science and Plant Analysis 2014;45:1934-1948.

5. Dayanand VRK, Mehta SM. Boosting mustard production through front line demonstrations. Indian Res J Ext Edu 2012;12(3):121-123.

6. FAO. FAOSTAT 2007. Food and Agriculture Organization of the United Nations, Rome, Italy http://faostat.fao.org/site/526/default/aspx.

7. Kangali, Sarita A. Study on impact of frontline demonstration of chickpea in Sehore district of Madhya Pradesh. M.Sc. (Ag.) Thesis Submitted to the Rajmata Vijayaraje Scindia Krishi Vishwa Vidyalaya, Gwalior 2012.

8. Kirar BS, Mahajan SK, Nashine R. Impact of technology practices on the productivity of soybean in FLD. Ind. Res. J Ext. Edu 2004;5(1):15-17.

9. Kumar J, Srivatava E. Impact of reproductive duration on yield and its component traits in lentil. Legume Research 2015;38(2):139-148.

10. Materne, Reddy AA. Commercial cultivation and profitability, (In) The Lentil - An Ancient Crop forModern Times, [S. S. Yadav, David McNeil and Philip C. Stevenson (Eds.), Springer], Rotterdam, The Netherlands 2007, P173-186.

11. Reddy AA. Pulses production technology: Status and way forward. Economic and Political Weekly 2009;44 (52):73-82.

12. Samui SK, Mitra S, Roy DK, Mandel AK, Saha D. Evaluation of front line demonstration on groundnut., $\mathrm{J}$ Indian Soc. Sostal Agric. Res 2000;18(2):180-183.

13. The Hindu. The Hindu Survey of Indian Agriculture 2005.

14. Verma, Deependra Prakash A study on impact of Front Line Demonstrations on pulses by Krishi Vigyan Kendra, Panna M.P. M.Sc. (Ag.) Thesis Submitted to Jawaharlal Nehru Krishi Vishwa Vidyalaya, Jabalpur 2013. 